\title{
Relation between sputum sol phase composition and diagnosis in chronic chest diseases
}

\author{
T. D. BR OGAN, H. C. RYLEY, LYNNE ALLEN, and \\ H I L A R Y HUT T \\ Department of Medical Microbiology, Welsh National School of Medicine, \\ Cardiff Royal Infirmary
}

\begin{abstract}
Sixty-four patients with various chest diseases were divided on clinical grounds into those suffering from asthma, chronic bronchitis, and chronic bronchitis with heart failure and those with damage to the lung parenchyma. A 24-hour specimen of sputum was collected from each patient and the electrolyte, protein, and carbohydrate composition was determined on the sol phase which was separated by ultracentrifugation. High variance was encountered in all the results and no difference in average $\mathrm{pH}$ and ionic concentration was found between the four groups. The average sol phase carbohydrate concentration and the average proportion of albumin in the sol phase high-molecular-weight substances differed between the groups and appeared to be related to the diagnosis of asthma and bronchitis. We think that the proportion of albumin in sputum sol phase high-molecular-weight substances might hold promise as a criterion for distinguishing between asthma and chronic bronchitis.
\end{abstract}

Chronic bronchitis and asthma are diseases characterized by hypersecretion of mucus, and both cause considerable morbidity and mortality. Chronic bronchitis is responsible for an annual loss of 32 million working days and for 30,000 deaths a year (Lowe, 1969). Although the number of deaths per annum from asthma is less than one tenth of that from bronchitis, between 1959 and 1966 the annual death rate for asthma more than doubled in the age group 15-34 years and increased eight-fold in the age group 10-14 years (Speizer, Doll, and Heaf, 1968a).

In spite of their prevalence, asthma and bronchitis are sometimes difficult to differentiate clinically, and cases have been reported in which necropsy findings were entirely in conflict with the clinical assessment of the patient in life (Speizer, Doll, Heaf, and Strang, 1968b). In children, it is not easy to distinguish between asthma and wheezy bronchitis although it is possible, by reference to age of onset and frequency of episodes in the first year of symptoms, to identify the group who will continue to suffer from asthma at the age of 10 years (Williams and McNicol, 1969). At the other extreme of life, asthma of late onset may occur in patients with long-standing bronchitis, and for this reason patients older than 64 years were excluded from the survey of Speizer et al. (1968a).
Mucus hypersecretion is a common feature of both asthma and bronchitis and we thought that biochemical examination of sputum might provide objective criteria that could help tof differentiate between the two diseases. Mucus however, is a non-homogeneous substance thab cannot be examined directly, but a method involving ultracentrifugation has been devisedo that enables separation of the continuous or so $\mathrm{B}$. phase from the gel phase, thus making possible an analysis of the water-soluble constituents of the mucus (Ryley and Brogan, 1968). The present investigation was carried out to see whether the composition of the sol phase of sputum from? patients suffering from various chest diseases was in any way related to the clinical assessment of their condition.

\section{PATIENTS AND METHODS}

PATIENTS The 64 patients in the study were all undef treatment at various hospitals of the United Cardiff group except four who were entirely under the care ${ }^{+}$ of their own general practitioner. The patients wereृd divided into four groups as follows:

Group I (29 patients) These were diagnosed a suffering from asthma on the clinical criterion of intermittent airways obstruction. Of this group $50 \%$ had eosinophils and other asthmatic stigmata in the 
FIG. 1. Electrophoretic patterns of the sol phase of sputum from (I) a patient with asthma and (II) a patient with chronic bronchitis, showing the resolution of the highmolecular-weight substances into the albumin $(A)$ band, the lysozyme $(L)$ band, and the bands of the glycoprotein fractions $M 1$, M2, and M3. A post albumin line $\left(A^{1}\right)$ can also be seen in the sol phase electrophoretic pattern of the asthmatic patient.

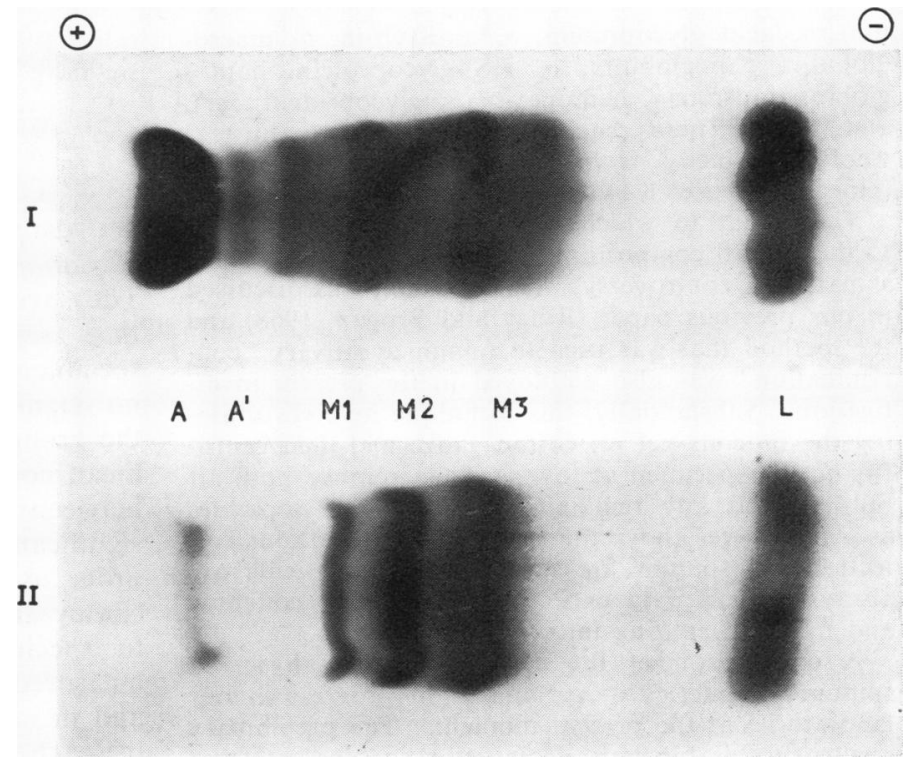

sputum, and $75 \%$ had shown evidence of response to steroid therapy. The average age \pm S.D. of the group was $53 \pm 19$ years and the number of women patients was four.

Group II (19 patients) Patients of this group were diagnosed as suffering from simple, mucopurulent or obstructive chronic bronchitis on the criteria of the M.R.C. Committee on the Aetiology of Chronic Bronchitis (1965). Included in this group were patients who had suffered an episode of cardiac failure which had become compensated. The average age \pm S.D. of the group was $64 \pm 6$ years and the number of women patients was two.

Group III (9 patients) These patients were also suffering from chronic bronchitis but clinically were in cardiac failure which had not responded to therapy at the time of collection of the sputum specimen. The average age \pm S.D. of the group was $69 \pm 6$ years and the number of women patients was one.

Group IV (7 patients) This group was composed of patients with evidence of damage to the lung parenchyma resulting from conditions such as neoplasm, lung abscess, etc. The average age \pm S.D. of the group was $59 \pm 15$ years and the number of women patients was two.

BIOCHEMICAL EXAMINATION OF THE SOL PHASE OF THE SPUTUM Sputum specimens were collected over a period of 24 hours and the continuous or sol phase was separated by centrifuging at $118,000 \times \mathrm{g}$ at $4^{\circ} \mathrm{C}$ for 4 hours in the SW 39 rotor of a model L2 Spinco ultra-centrifuge (Beckman Instruments Ltd., California, U.S.A.). The concentrations of $\mathrm{H}^{+}, \mathrm{Na}^{+}$,
$\mathrm{K}+, \mathrm{Cl}^{\prime}, \mathrm{PO}_{4}^{\prime \prime}$, protein, and carbohydrate were determined as described previously and data or specimen to specimen variations in individual patients have been published in some detail (Ryley and Brogan, 1968).

The proportions of the soluble high-molecularweight components were estimated by electrophoresis using a modification of the method described by Ryley (1970). Five microlitre aliquots of the sol phase were applied in duplicate to $10 \times 2.5 \mathrm{~cm}$ cellulose acetate strips (Millipore Filter Corporation, Watertown, Mass., U.S.A.) along $1 \mathrm{~cm}$ lines at 3.5 cm from the cathodal end of the strip. Electrophoresis was carried out at a current density of 0.3 $\mathrm{mA}$ per $\mathrm{cm}$ width for $35 \mathrm{~min}$ in a triscitrate-borateglycerol $^{1}$ buffer (Ryley, 1970), pH 8.75, after which the strips were dried and stained with $0.2 \%$ Ponceau $\mathbf{S}$ in $3 \%$ trichloroacetic acid. This separated the albumin (A) and lysozyme (L) bands and resolved the glycoprotein component into three lines which were designated M1, M2, and M3 (Fig. 1); in some samples, a post-albumin line (A') was also resolved. The proportions of these components were determined by eluting each band with $2 \mathrm{ml}$ of $0.2 \mathrm{M}$ $\mathrm{NaOH}$, acidifying the alkaline extract with $0.1 \mathrm{ml}$ of glacial acetic acid and measuring the optical density of the solutions in $40 \mathrm{~mm}$ micro glass cells at 530 nm with a Unicam SP 500 spectrophotometer (Unicam Instruments Ltd., Cambridge).

Immunodiffusion was carried out by the Ouchterloney double diffusion microtechnique using a method closely similar to that described by Clausen (1969). Each sol phase was tested against rabbit antisera to the following plasma proteins: pre-albumin, albu${ }^{1}$ tris, $37.5 \mathrm{~g}$; citric acid, $1.5 \mathrm{~g}$; boric acid, $3.8 \mathrm{~g}$; glycerol, $60 \mathrm{ml}$; distilled water, to 1 litre. 
min, $\alpha_{1}$ acid glycoprotein, $\alpha_{1}$ antitrypsin, $\alpha_{2}$ macroglobulin, $\beta_{1 \mathrm{~A}}$ globulin, $\alpha_{2}$ HS glycoprotein, haptoglobin, transferrin, hemopexin, $\beta_{2}$ glycoprotein, IgA, and IgG. These reagents (Behringwerke antisera) were obtained frcm Hoechst Pharmaceuticals (Hoechst House, Kew Bridge, London).

The extent to which saliva makes a contribution to the overall composition of sputum has always been a matter of controversy. This question was discussed in our previous paper (Ryley and Brogan, 1968) and the method that was used to minimize salivary 'contamination' was also employed in the present investigation. Substantially, this technique involves draining the mucous gel on cotton gauze and then centrifuging the specimen at low speed to remove both air bubbles and any remaining saliva, which separates as a fluid layer above the gel. Twenty-four-hour collections of sputum are made and the patients are always instructed to expectorate only after coughing and to avoid spitting into the containers.

A comparison of the composition of saliva and sputum in a series of patients is in progress in our laboratories at the present moment. The preliminary results of this biochemical investigation indicate that some 10 major secretory proteins and glycoproteins are present in both saliva and sputum although their relative concentrations are higher in sputum than in saliva. Thus, none of these components can be used as an index of salivary 'contamination'. Plasma proteins, however, appear to be present in saliva only in low concentrations. Minor components of small molecular size are under close scrutiny and it is hoped that differences here may help, in the future, to estimate the extent of salivary 'contamination'; it may be some time before such parameters can be used with confidence.

Work is continually in progress at this centre on sputum from patients with chronic bronchitis, asthma, and cystic fibrosis. The preliminary findings on the comparison of saliva and sputum appear to accord with the opinion of Reid (1967) that salivary 'contamination' of properly collected sputum samples does not constitute a problem. We are confident that salivary 'contamination' had little effect on the data we have submitted for publication.

\section{RESULTS}

SPUTUM SOL PHASES OF THE 4 GROLPS OF PATIENTS Variation in proportions and ionic concentrations. The average proportion \pm S.D. of the mucus $\vec{\omega}$ that separated as sol phase from sputum specimens of all 64 patients was $71 \pm 18 \%$ and $\vec{x}$ no significant differences were found between $\hat{\sim}_{\tilde{N}}$ the groups. Differences in average $\mathrm{pH}$ and in the mean concentrations of $\mathrm{Na}^{+}, \mathrm{K}^{+}, \mathrm{Cl}^{\prime}$, and $\mathrm{PO}_{4}^{\prime \prime}+$ between the four groups also failed to achieve $\vec{\infty}$ significance and their values were of the same윽 order as those determined in a previous study (Ryley and Brogan, 1968). Considerable specimen to specimen variation was encountered in the $₹$ measured values within each group of patients. $\vec{\varphi}$ and in no group could any relationship be estab- $-\overrightarrow{ }$ lished between variation in sol phase ionic concentration and in the proportion of mucuso separating as sol phase.

Concentration and proportions of high-molecu- $\stackrel{\mathscr{Q}}{\mathbb{Q}}$ lar-weight components The results of the protein and carbohydrate estimations that were carried $\frac{0}{3}$ out on the sputum of the four groups of patients are given in Table I.

The average total protein concentration of the sputum sol phases did not differ significantly $\vec{\partial}$ between the asthmatic patients (group I) and the bronchitic group (groups II and III) but a significantly higher $(\mathrm{P}<0.02)$ mean total protein con- 3 centration was found in the sol phases of sputum from bronchitic patients in heart failure (group III) as compared with bronchitic patients not in $\mathrm{O}$ cardiac failure (group II).

T A B L E I

AVERAGES OF CONCENTRATIONS AND PROPORTIONS OF HIGH-MOLECULAR-WEIGHT COMPONENTS IN SPUTUM SOL PHASES

(The mean proportions of albumin, glycoprotein, and lysozyme are expressed as percentages of the total high-molecular-weight substances.)

\begin{tabular}{|c|c|c|c|c|c|c|c|c|}
\hline & \multicolumn{2}{|c|}{ Group I } & \multicolumn{2}{|c|}{ Group II } & \multicolumn{2}{|c|}{ Group III } & \multicolumn{2}{|c|}{ Group IV } \\
\hline & Mean \pm S.D. & $\begin{array}{l}\text { No. of } \\
\text { Patients }\end{array}$ & Mean \pm S.D. & $\begin{array}{l}\text { No. of } \\
\text { Patients }\end{array}$ & Mean \pm S.D. & $\begin{array}{c}\text { No. of } \\
\text { Patients }\end{array}$ & Mean \pm S.D. & $\begin{array}{l}\text { No. of } \\
\text { Patients }\end{array}$ \\
\hline Total protein ${ }^{1}$ & $582 \pm 285$ & 29 & $597 \pm 208$ & 19 & $928 \div 461$ & 9 & $694 \pm 504$ & 7 \\
\hline $\begin{array}{l}\text { Carbohydrate precipitated } \\
\text { by } 75 \% \text { ethanol: } \\
\text { Albumin }(\%)\end{array}$ & $\begin{array}{c}105 \pm 72 \\
22 \cdot 1 \pm 10 \cdot 1\end{array}$ & $\begin{array}{l}24 \\
27\end{array}$ & $\begin{array}{c}162 \pm 86 \\
13 \cdot 6 \pm 6 \cdot 2\end{array}$ & $\begin{array}{l}18 \\
19\end{array}$ & $\begin{array}{c}172 \div 132 \\
18.0 \pm 4.6\end{array}$ & $\begin{array}{l}8 \\
8\end{array}$ & $\begin{array}{r}144 \pm 182 \\
21 \cdot 4 \pm 9 \cdot 3\end{array}$ & $\begin{array}{l}7 \\
7\end{array}$ \\
\hline $\begin{array}{l}\text { Glycoprotein (M) } \\
\text { component (\%) } \\
\text { Glycoprotein fraction } \begin{array}{l}\text { M1 }(\%) \\
\text { M2 }(\%) \\
\text { Lysozyme }(\%)\end{array} \quad \text { M3 }(\%)\end{array}$ & $\begin{array}{l}60 \cdot 0 \pm 9 \cdot 5 \\
11 \cdot 0=3 \cdot 6 \\
21 \cdot 0 \pm 6 \cdot 8 \\
28 \cdot 4 \pm 7 \cdot 0 \\
18 \cdot 6 \pm 8 \cdot 5\end{array}$ & $\begin{array}{l}27 \\
24 \\
26 \\
27 \\
26\end{array}$ & $\begin{array}{l}67 \cdot 3 \div 7 \cdot 4 \\
11 \cdot 6 \pm 4 \cdot 9 \\
23 \cdot 7 \pm 7 \cdot 7 \\
35 \cdot 6 \div 9 \cdot 5 \\
19 \cdot 8 \div 8 \cdot 0\end{array}$ & $\begin{array}{l}19 \\
13 \\
16 \\
16 \\
19\end{array}$ & $\begin{array}{l}70 \cdot 3+4 \cdot 8 \\
11 \cdot 2=3 \cdot 5 \\
19 \cdot 6=10 \cdot 3 \\
43 \cdot 5=11 \cdot 2 \\
11 \cdot 9=7 \cdot 3\end{array}$ & $\begin{array}{l}8 \\
5 \\
8 \\
8 \\
8\end{array}$ & $\begin{array}{l}62 \cdot 6 \pm 10 \cdot 1 \\
12 \cdot 8 \pm 4 \cdot 0 \\
16 \cdot 7 \div 6 \cdot 6 \\
38 \cdot 7 \div 11 \cdot 6 \\
16 \cdot 1=3 \cdot 4\end{array}$ & $\begin{array}{l}7 \\
4 \\
6 \\
6 \\
7\end{array}$ \\
\hline
\end{tabular}

mg, as albumin, $/ 100 \mathrm{ml}$ sol phase.

$2 \mathrm{mg}$, as galactose $100 \mathrm{ml}$ sol phase. 
The average proportion of albumin in the sol phase high-molecular-weight substances was significantly higher $(P<0.01)$ in sputum from patients with asthma (group I) than from those with bronchitis (group II) and the data are illustrated (Fig. 2). There was a similar difference between the proportion of albumin in the sol phases of patients suffering from damage to the

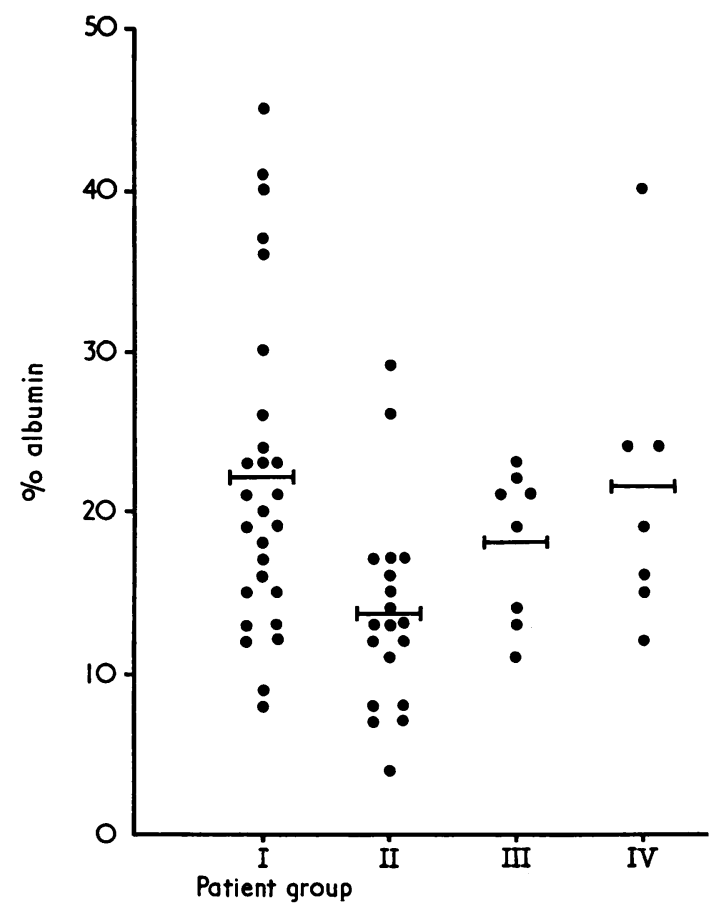

FIG. 2. Distribution of the proportions of serum albumin in the sputum sol phase high-molecular-weight substances within the four groups of patients. The mean percentage of albumin in each group is shown by the symbol lung parenchyma (group IV) and of those with bronchitis. The apparent difference between the mean proportion of albumin in the sol phases of group II (bronchitis) and group III (bronchitis with heart failure) patients did not achieve significance $(0.05<\mathrm{P}<0.1)$ in contrast with the difference that was found between the mean sol phase total protein concentration of the two groups.

The mean concentration of ethanol-precipitated carbohydrate in the sol phases was greater in sputum from bronchitic patients (groups II and III) than from those with asthma $(\mathrm{P}<0.02)$ and this was also reflected in the difference between the proportions of the glycoprotein (M) component in the sol phase high-molecular-weight substances of the groups. The significantly higher proportion $(\mathrm{P}<0.01)$ of the M3 fraction of this component in sol phases from bronchitic as compared with asthmatic patients accounted for this difference since there was no significant variation between the groups in the proportions of the M1 or M2 glycoprotein fractions.

The only difference that was found in the proportions of lysozyme in the sol phases of the four groups was that between groups II and III (bronchitis without, and with, heart failure; $002<\mathrm{P}<0.05)$; none of the other differences achieved significance.

Variation in types and numbers of plasma proteins detected The frequency of occurrence of 13 plasma proteins in the sputum sol phases of the four groups of patients is given in Table II. Albumin, IgA, and IgG were invariably found in all sputum sol phases. Transferrin, $\alpha_{1}$ acid glycoprotein, haptoglobin, $\alpha_{1}$ antitrypsin, and $\beta_{1 \mathrm{~A}}$ globulin were also commonly found in all

T A B L E I I

FREQUENCY OF OCCURRENCE OF 13 PLASMA PROTEINS IN THE SPUTUM SOL PHASES

\begin{tabular}{|c|c|c|c|c|}
\hline & \multicolumn{4}{|c|}{ Proportion of Sol Phases Containing the Corresponding Protein } \\
\hline & $\underset{\text { (23 patients) }}{\text { Group I }}$ & $\underset{\text { (16 patients) }}{\text { Group II }}$ & $\begin{array}{c}\text { Group III } \\
\text { (8 patients) }\end{array}$ & $\underset{\text { (7 patients) }}{\text { Group IV }}$ \\
\hline $\begin{array}{l}\text { Albumin } \\
\text { IgA } \\
\text { IgG } \\
\text { Transferrin } \\
\alpha_{1} \text { acid glycoprotein } \\
\text { Haptoglobin } \\
\alpha_{1} \text { antitrypsin } \\
\beta_{1} \text { A globulin } \\
\text { Haemopexin } \\
\beta_{2} \text { glycoprotein } \\
\alpha_{2} \text { HS glycoprotein } \\
\text { Pre-albumin } \\
\alpha_{2} \text { macroglobulin }\end{array}$ & $\begin{array}{l}1.000 \\
1.000 \\
1.000 \\
0.913 \\
0.652 \\
0.7391 \\
0.695 \\
0.608 \\
0.434 \\
0.217 \\
0.130 \\
0.130 \\
0.043\end{array}$ & $\begin{array}{l}1 \cdot 000 \\
1.000 \\
1.000 \\
0 \cdot 875 \\
0.750 \\
0.312^{1} \\
0.687 \\
0.437 \\
0.312 \\
0 \cdot 063 \\
0 \\
0 \\
0\end{array}$ & $\begin{array}{l}1 \cdot 000 \\
1 \cdot 000 \\
1 \cdot 000 \\
1 \cdot 0000 \\
1 \cdot 000 \\
1 \cdot 000 \\
1 \cdot 000 \\
1 \cdot 0000 \\
0 \cdot 750 \\
0 \cdot 250 \\
0 \cdot 125 \\
0 \\
0 \cdot 125\end{array}$ & $\begin{array}{l}1.000 \\
1.000 \\
1.000 \\
1.000 \\
1.000 \\
1.000 \\
1.000 \\
1.000 \\
0.714 \\
0 \cdot 143 \\
0.143 \\
0 \\
0\end{array}$ \\
\hline
\end{tabular}

1 Difference in proportions significant $(P<0.05)$ 
four groups. Haptoglobin was detected in a higher proportion $(\mathrm{P}<0.05)$ of the sol phases of the asthmatic group I than in those of the bronchitic group II but none of the other differences was significant.

An apparently greater number of plasma proteins was detected in the sol phases of the asthmatic group than in those of the bronchitic group II. When the data were analysed by the MannWhitney U test (Siegel, 1956) the difference failed to achieve significance $(0.05<\mathrm{P}<0 \cdot 1)$. This test, however, showed that a stochastically greater number of plasma proteins was detected in the sol phases of group III as compared with group II patients $(P<0.001)$, a difference similar to that found between the average concentrations of total protein in the sol phases of the two groups.

\section{DISCUSSION}

It was possible to divide the 64 patients in this study into four groups but each of these was a heterogeneous population. Patients with asthma of late onset superimposed on long-standing bronchitis were included in group I, and this probably accounted for the greater diversity of ages in this group as compared with the bronchitic groups. Patients suffering from simple, mucopurulent, and obstructive chronic bronchitis were all included in group II, but those with overt cardiac failure were placed in a separate category (group III). It was not possible by clinical assessment to identify those patients in whom treatment had failed to control active inflammation resulting from infection.

No significant differences were found between the groups in the proportion of mucus separating as sol phase or in the $\mathrm{pH}$ and ionic concentrations of the sol phases, and high variance occurred in all the results. It has been suggested by Ryley and Brogan (1968) that the proportion of sol phase is related to the water content of the ground substance of sputum. Newcomb and DeVald (1969) have postulated that large variation in sputum composition from specimen to specimen is due to fluid loss by evaporation and re-absorption of water in the airways. In the present investigation, the absence of any relation between the variation in proportion of mucus separating as sol phase and that of the ionic composition of the sputum sol phases suggests that loss of fluid by evaporation does not account for gross specimen to specimen variation in sputum composition. It would seem, therefore, that re-absorption of water by the bronchial mucosa is the limiting factor that determines the viscidity of sputum in chronic chest diseases.

The secretory character of the continuous phase of sputum in bronchitis was shown by the higher concentration of ethanol-precipitated carbohydrate and the higher proportion of glycoprotein in the sol phase high-molecular-weight substances in bronchitic as compared with asthmatic patients. The M3 fraction of the glycoprotein was mostly responsible for the elevation of the proportion of glycoprotein in the bronchitic patients, and the composition of this fraction is now under investi- No gation and has been shown to contain a metastable macroglycoprotein component (Ryley, unpublished observations).

The average proportion of albumin in the sol 은 phase high-molecular-weight substances of asth- $\vec{c}$ matic patients was similar to that of the sputum sol phases from patients suffering from damage to the lung parenchyma, and was significantly higher than the corresponding proportion of .albumin in the sol phases of patients with bronchitis. This difference in character between the high-molecular-weight substances of the sputum sol phases in asthma and bronchitis was not unexpected as the syndrome of asthma is $\stackrel{\mathbb{Q}}{\mathscr{Q}}$ probably the result of tissue-damaging immune $\overrightarrow{\vec{A}}$ reactions although the pathogenesis of non- $\frac{O}{3}$ allergic ' intrinsic' asthma is still obscure (TurnerWarwick, 1969).

High proportions of sol phase albumin in some individual bronchitic patients could have been the 을 result of infection inadequately controlled by $\underset{x}{\otimes}$ therapy. This, however, remains a speculation as the mere presence of pathogens in sputum is of little diagnostic value (Medici and Bürgi, 1965) and $\delta$ such a hypothesis would have to be tested in conjunction with criteria of active inflammation such 욱 as sputum DNA and LDH levels (Bürgi et al., $>$ 1968). The haemodynamic disturbances of cardiac failure probably accounted for the eleva- $N$ tion in total protein and in the number of plasma proteins of sputum sol phases from bronchitic $N$ patients in heart failure. These vascular disturb- $\underset{\omega}{N}$ ances could also have caused the elevation in the proportion of albumin in the sol phase high-e molecular-weight substances that was found in $\frac{\mathbb{D}}{\mathbb{2}}$ more than half the patients in this group, but the? difference in the mean albumin values was not 0 significant statistically between the groups of $\stackrel{\vec{D}}{\circ}$ patients suffering from bronchitis with and without the complication of cardiac failure.

The frequency of occurrence of various plasmao proteins in the sputum sol phases did not differ markedly between the groups of patients. 
$\alpha_{1}$-Antitrypsin was found in a high proportion of both asthmatic and bronchitic sol phases, a finding of interest in view of the possible association of this plasma protein with those chronic lung diseases which have obstructed airways (Kueppers and Bearn, 1966). Haptoglobin was detected in a greater proportion of sol phases from asthmatic than bronchitic patients but the meaning of this difference is not yet clear.

Sputum is a non-homogeneous secretion that cannot be examined directly, but the relatively simple technique of ultracentrifugation causes an average proportion of $70 \%$ of the ground substance to separate as sol phase containing the water-soluble components in concentrations comparable with those of the original mucus. The high coefficients of variation encountered in the estimations were probably a measure of the many factors that operate in the control of bronchial secretion but it is possible that some of these were due to the heterogeneous nature of the population of patients under study. We think that the proportion of albumin in the sputum sol phase high-molecular-weight substances holds promise as a criterion for distinguishing between asthma and bronchitis. The derivation of an albumin value that would be of use in the differentiation between these diseases will have to await the completion of a highly selected population of asthmatic and bronchitic patients.

We thank Professor Scott Thomson for his continuing interest and advice during the course of this work. We are also indebted to Dr. D. A. Williams of the Asthma and Allergy Research Unit, St. David's Hospital, Cardiff, and to other physicians of the United Cardiff Hospitals and general practitioners of the Cardiff area for access to patients under their care.

This investigation was supported by a M.R.C. research grant and a clinical research grant from the United Cardiff Hospitals.

\section{REFERENCES}

Bürgi, H., Wiesmann, U., Richterich, R., Regli, J., and Medici, T. (1968). New objective criteria for inflammation in bronchial secretions. Brit. med. J., 2, 654.

Clausen, J. (1969). In Laboratory Techniques in Biochemistry and Molecular Biology, vol. 1, p. 521, edited by T. S. Work and E. Work. North Holland Publishing Company, Amsterdam.

Kueppers, F., and Bearn, A. G. (1966). A possible experimental approach to the association of hereditary $a_{1}$ antitrypsin deficiency and pulmonary emphysema. Proc. Soc. exp. Biol., N.Y., 121, 1207.

Lowe, C. R. (1969). Industrial bronchitis. Brit. med. J. 1, 463,

M.R.C. Committee on the Aetiology of Chronic Bronchitis (1965). Definition and classification of chronic bronchitis for clinical and epidemiological purposes. Lancet, $1,775$.

Medici, T., and Bürgi, H. (1965). Desoxyribonucleinsaüren (Zur Virulenz der im Sputum nachgewiesenen bronchopathogenen Mikroorganismen). Schweiz. med. Wschr., 95, 1679.

Newcomb, R. W., and DeVald, B. (1969). Protein concentrations in sputa from asthmatic children. Albumin, lactoferrin, $\gamma \mathrm{A}$ and $\gamma \mathrm{G}$. J. Lab. clin. Med., 73, 734.

Reid, L. (1967). Mucus secretion and chronic bronchitis. Med. Thorac., 24, 40.

Ryley, H. C. (1970). An electrophoretic study of the sol phase of sputum. J. Lab. clin. Med. 75, 382.

- and Brogan, T. D. (1968). Variation in the composition of sputum in chronic chest diseases. Brit. J. exp. Path., 49, 625 .

Siegel, S. (1956). In Non-parametric Statistics for the Behavioral Sciences, p. 116. McGraw-Hill, New York.

Speizer, F. E., Doll, R., and Heaf, P. (1968a). Observations on recent increase in mortality from asthma. Brit. med. $J ., 1,335$.

- and Strang, L. B. (1968b). Investigation into use of drugs preceding death from asthma. Brit. med.J., $1,339$.

Turner-Warwick, M. (1969). Advances in asthma: hypersensitivity mechanisms. Brit. med. J., 4, 355.

Williams, H., and McNicol, K. N. (1969). Prevalence, natural history, and relationship of wheezy bronchitis and asthma in children. An epidemiological study. Br. med. J., 4, 321. 